\title{
THE RELEVANCE OF FOREIGN LANGUAGE TEACHING MATERIALS IN HIGH SCHOOL (SMA) TO CULTURAL PRESERVATION AND TOURISM DEVELOPMENT IN TABANAN DISTRICT
}

\author{
I Gede Putu Widarmana \\ STPBI ATC
}

\begin{abstract}
Bali is one of a very famous tourist destination in the world. Many things can be developed as tourism objects in each district in Bali. One of them is Tabanan regency that offers some choices to visit, which is very famous for its natural beauty attractions. Tourism in Tabanan can be developed by strengthening the human resources that involved in it, which can be through the teaching of foreign languages, such as English that is generally given at school. However, the issue may arise whether foreign language teaching is able to support the attitudes to preserve the culture and able to develop tourism in Tabanan. Therefore this study was held to address issues intended to see the relevance of learning foreign language in Senior high school with cultural preservation and development of tourism in Tabanan. The research method used is descriptive with multiple-case study sites. The results show that the teachers have done their job in teaching using materials that are recommended by the curriculum, but the impact of the preservation and development of tourism in Tabanan is still quite low, which is caused by the material used is less related to the cultural preservation and tourism development. Therefore it is advisable to make some changes in the teaching of foreign language in the future.
\end{abstract}

Keywords: foreign language teaching material, cultural preservation, tourism development

\section{Introduction}

\section{Background of the Study}

Bali is already famous for one of the top tourism attractions in the world. Each district offers many tourism attractions. It seems that the number can be limitless since literally anything can be developed as tourism attractions in Bali. Tabanan is one of the districts in Bali that also offers various tourism objects that is still developing its quality like what other districts like Badung and Denpasar have, so many tourists will visit Tabanan more often. If we may take a quick glance, Tabanan has like tons of tourism attractions spread out in the area like the famous offshore temple of Tanah Lot or the beauty of rice fields of Jatiluwih. For additional information, Tanah Lot tourism object in Tabanan still holds the top visited tourism destination among many other tourism object in Bali from 20032014 based on data collected by Tourism Department of Bali, with more than 3 
million visits in 2014 .

There is one way the Tabanan government has done, and still be doing, to improve the quality of their tourism sector. One of them is by improving the quality of human resources that involve in the tourism industry. The way to do that is by improving their foreign language use, especially English proficiency. But the problem is that English proficiency in Indonesia is still below some of its neighboring countries, the ASEAN. Based on the research conducted by English First (EF), Indonesia holds the 6th position among the 14 Asian countries in terms of English Proficiency Index (EPI), below Malaysia and Singapore. Whereas among 63 countries in all over the world, Indonesia is in the 28th position in terms of the EPI (Antaranews. 2015).

As one of its top income contributors, Tabanan needs to improve the tourism quality in terms of its human resources including English teachers. Many things can be done by the English teachers regarding cultural preservation and tourism development, as one of them is setting up learning materials for users, in this case, the region. But the current problem is that many schools are not aware of the issue that English can be used as tools to improve tourism development in the area, as well as preserving culture through the learning process. The problem may happen due to the lack of understanding of the importance of the tourism development and cultural preservation or lack of information regarding the issue that they have from their superior. Ideally as what have been stated in the curriculum, English learning should support and accommodate region's need, that will help the region to get ready to compete in the future global competition like the coming Asia Pacific Economic Cooperation in 2020.

Based on the above statement there are some problems that can be identified, as: 1) the low quality of English proficiency should be well treated with the help of the local government, 2) English learning at school has not fully accommodated material development that include tourism development and culture preservation as the main source of the region, 3) the lack of stakeholders awareness to make a certain synergy between the syllabus and region's need. The absence can be seen from the end evaluation of National Test (UN) or TOEFL material as standardized test to evaluate the students, whereas KTSP or the current curriculum (K13) states that students' evaluation is classroom-based assessment and authentic assessment.

\section{Research Problems}

Educational system should be well managed if Tabanan want to improve its human resources, especially the foreign language learning. One innovated way to make it works is to make it relevant to the region need analysis. This research is trying to find out whether the English material in high school is relevant to support tourism development and cultural preservation in Tabanan or not. Here are the lists of the research problems:

1. How the English learning material and evaluation in Senior High Schools in Tabanan are managed to meet the current curriculum, syllabus, type and function of the material, teacher and students' role, as well as its relevance to the need of the region?

2. What the Senior High School Teachers have done to develop their English 
material?

3. What is the agreement reached by the teachers for the material and evaluation to be relevance to the culture preservation and tourism development in Tabanan?

\section{Research Objectives}

The objective of this study is to obtain a description of:

1. The English language learning materials and evaluation in Senior High School.

2. The efforts of the teachers in developing the learning material.

3. The agreement of the teachers to set learning materials and evaluation by regarding cultural preservation and tourism development in Tabanan district.

\section{Literature Review}

\section{English Learning Materials}

Language instruction has five important components; students, teachers, materials, teaching methods, and evaluations (Kitao. 1997). Materials are deemed important in the statement since that materials control learning and teaching (Allwright in Kitao. 1997). As we can see in teaching or learning process, students as well as teachers depend hardly on the presents of material. Take for instance a textbook. Students learn what is presented in the book while students also learn how the material is being presented from there. That might be the only way students can learn something. However the statement might not be solely true since there are also experience teacher that can teach without using the presence of textbook in the class.

Teaching/learning materials are broadly refers to a spectrum of educational materials that teachers use in the classroom to support learning objectives, as set out in lesson plans (Lewis in k6educators.com). Lewis added that the materials can be in many things, like story book, videos, games, model clay, LCD projector. It is clearly stated that textbook is not the only material that can be used in the class. But many teachers still use textbook as the only way to present the lesson for their students in the class. UNESCO in one of its articles sates that in poor countries, with untrained teachers, the textbook becomes the most important, if not the only vehicle for the curriculum.

Teacher, materials, curriculum, methods, or evaluation should be less of our concern than the learner itself (Kitao, 1997). Teacher can use many teaching techniques, uses many materials, follows instructions presented in the curriculum and in the end evaluates students or grades them, but still the leaners should be the center of teaching/leaning process. That is why our education policy makers have designed curriculum that fit the need of the learners. Obviously, KTSP and K13 are basically design to put learners as the center of the learning process, which also regarding local needs. Both curriculums have been made in certain way that includes materials as one of it means to present the knowledge to the students. Teachers may elaborate, adapt, and supplement those materials that they fit the students need. However, teacher seems to rely so much from material 
as the only source of instruction since many teachers are busy and do not have time to prepare any other materials that is also important in language instruction.

\section{Culture and its Preservation}

Culture has far more greater meaning than just related to art or heritage of the native. Culture should be applied to both dominant and minority population in both developed and developing countries (Thomas-Hoffman, 2012). Furthermore Thomas-Hoffman based on World Conference on Cultural Policies in Mexico City (1982), defined culture as the whole complex of distinctive spiritual, material, intellectual and emotional features that characterize a society or social group. It is clearly stated that culture has broaden meanings than only arts and letters, but also modes of life, the fundamental rights of the human being, value systems, traditions, and beliefs.

Koentjaraningrat (2002) put cultural understanding into two categories. The first one, cultural understanding can be put in the narrow sense as the mind or work and the work of human beings who fulfil the desire for beauty, while the second one in the sense of universal, that is all human activities excluding instinct or the total human mind or work of man that is not coming from the instincts, therefore it can only be initiated through learning process.

One organization of the UN, UNESCO, has already encouraged the identification, protection and preservation of cultural and natural heritage around the world considered to be outstanding value to humanity. The commitment is embodied in an international treaty called the Convention concerning the protection of the World cultural and Natural Heritage, which was adopted since 1972 (UNESCO. 2015). Especially for the world heritage, as added by UNECSO, what makes it special is that world heritage sites belong to all the peoples of the world, irrespective of the territory on which they are located.

Furthermore Thomas-Hoffman (2012) also added three major ways of protecting and preserving the culture. The first one is law. It is important for every country to established law to protect culture within their boundaries. Later one, as the primary key to promoting understanding about the culture awareness is by education. Better education in the community, in the school system, or even in rural area will lead to better understanding to cultural diversity as well as cultural protection and preservation. And the last one is through Local Solutions. It is believed that the implementation of certain policies in preserving the culture should be in cooperation with the very society these programs and policies seek to protect.

From the concepts and statements above, it can be concluded that cultural preservation depends not only individually or certain community, but more than that it must be including all system of communities in the whole world.

\section{Tourism and its Development}

Tourism can be roughly defined as a short time temporary movement of people to a place outside their living area without any purpose of working (Burkart and Medlik in Soekadijo, 1993). Tourism is a major industry in Bali since it serves the main income of Bali. The development itself becomes standard tourism development of tourism in Indonesia (Bappenas. 2014). The importance 
of tourism has made the government to state the field as one of top sector to be well developed.

However, in their Tourism Developing Guide, Alberta, Canada stated that developing tourism industry is significantly different from developing other area. It states few unique things about tourism development. They are:

1. Changing trends will make tourism market difficult to define.

2. Demands are based on seasons.

3. Unpredictable weather.

4. Consumer expectations are vary.

5. Long term market development.

6. Some business has high fix cost.

7. Cooperative nature of competition.

8. Limited use of asset.

9. Some have large up-front capital intensive.

Furthermore, the development of tourism should also ensure the sustainable of the tourism itself since the field is very important to prolong the economic certainty of our next generation. As what UNWTO (2005) states, "Tourism that takes full account of its current and future economic, social and environmental impacts, addressing the needs of visitors, the industry, the environment and host communities."

\section{Methodology}

This research was conducted in 5 Senior high schools in Tabanan regency. They are SMA N 1 Tabanan, SMA N 2 Tabanan, SMA N 1 Kediri, SMA N 1 Kerambitan, and SMA N 1 Penebel. This study did not use the terms population and sample, but research objects and subjects. The object of this study is the English language learning materials, while nine English teachers are as key informants.

This research uses multiple-sites case study where it contains a number of embedded cases wherein each embedded case includes multiple units of analysis (Yin, 2003 in Al Qur'an, 2010). Therefor the five senior high schools in this study are regarded as a multi-site study. In addition, Perry (2004) stated there are two major advantages of using a multiple-case design. They are; (1) Evidence is considered more compelling, and (2) Overall study is therefore regarded as more robust.

There are 3 variables in this study, namely: English learning materials (that includes the applicable curriculum, learning objectives, a model syllabus, the type and function of matter in the learning activities, the role of teachers and students in learning activities, and relevance of learning materials and evaluation with the needs of the Tabanan regency), Teachers' efforts in developing the material, and teachers' agreement to set learning materials and evaluation by regarding cultural preservation and tourism development in Tabanan district.

The data gathering in this research are conducted using instruments like observation sheet, valid documents such as curriculum, syllabus, textbook, and 
lesson plan, that are used by the teachers, and lists of in-depth interview questions to interview subject teachers.

\section{Results and Discussion}

\section{English Teaching Materials in Senior High School in Tabanan}

The research findings and discussion regarding English teaching materials will be covering six sub issues. The first one is about the applicable curriculum. The results showed that all schools have attempted to implement the current curriculum. Three schools have to apply the latest one, Kurikulum 2013 (K13), while the other two are using Kurikulum Tingkat Satuan Pendidikan (KTSP). However, less than half of the speakers who really understand the implementation, especially for those who are using K13. The schools that are using K13 are still facing difficulties to implement the curriculum since the curriculum is relatively new. The socialization and training from the government for teachers about the curriculum are on progress, which make some of the teachers that have not got any training must learn by themselves about K13. The result is their limited knowledge about K13 and its implementation in learning process as well as in using material based on the curriculum.

The second sub issue is about learning objectives. All the subject teachers said they have understood the English learning objectives in High School. Learning objectives in KTSP in general, that students are able to use English in Performative, Functional, and Epistemic way. While in K13, the English learning objective have been stated in the syllabus that has been given by the government.

The syllabus is our third sub discussion. All the subject teachers are already using standardize syllabus, whether they are applying KTSP or K13 in their school. Basically K13 syllabus has already given by the central government, Jakarta, while KTSP syllabus is made in their school, depends on their school and region need. However it is still under certain criteria provided by the government.

The fourth issue is the type and function of teaching materials in learning process. Schools that apply K13 are already given books from the central government. This is surely an ease for teachers in finding printed textbook. However, there are still some students in the schools aren't getting decent textbook from the government, therefor they are trying to copy their friend's or print it from the internet. Meanwhile, schools that are still using KTSP must provide textbook materials, which sometimes come from third parties supplier. These printed materials are teachers' prime choice to be used during learning process. Only 3 subject teachers said they also use additional materials from other sources like the internet or made them by themselves.

However, good use of text books and authentic materials or teacher-made materials as teaching materials has its own advantages and disadvantages. The advantages of textbook are; able to provide structure and syllabus for planning, provide standard learning, maintaining quality, efficient to use, and ensure the effectiveness of the model and input languages. While the drawbacks are: the language is not authentic, distorted content, do not reflect the needs of students, 
reducing the role of teachers' skills, and expensive.

Moreover, authentic material will be able to motivate the students, able to accommodate target culture, scientific language, able to comprehend the needs of the students, and encourage teachers to be more creative in their teaching approach. But some drawbacks may arise from authentic material compare to the material made in the teacher: the material made by the teacher may no less interesting to other materials, authentic material often shows a difficult and complex language, teacher-made material often much better than authentic material because it is based on steps of the syllabus, and authentic material often burdening teachers because the teacher have to prepare more extra time to develop activities and exercises than the teacher-made material.

The fifth sub issue is the role of teachers and students in teaching. It is quite obvious that students are the main concern during learning activities. Both KTSP and K13 state that the role of teacher is facilitating the learning activities and students must be active to do task or practice based on certain instruction that has been given by the teacher. Since the teacher uses text book materials or the ones that has been given by the central government, this will hold students creativity to explore other things like solving real problems, the ones that they usually have in their daily life. However based on interview and observation, all subject teachers are trying their best to accommodate the issue so that students are still able to perform maximum creativity, by setting up classroom situation like daily life activities. These activities are usually in the form of dialogue or group discussion.

The last sub issue is the relevance of the material and evaluation to the needs of the region. The referred material in this part is English language learning materials in accordance with the regional needs or the needs of the Tabanan regency concerning the preservation of culture and tourism development. As what have been stated above, all subject teachers are trying their best to accommodate leaning process to meet the standard student's centre activity, and providing other materials outside formal textbook. However only two of them are able to access other materials that are directly related to their local culture. The teachers are asking the students to find brochure or tourist handbook, where there are local tourism sites to be studied later on group discussion or oral performance in the class. The teacher said the activity will strengthen the students' knowledge about tourism sites in their area and hopefully raise their awareness that the sites must be well preserved for future benefit.

\section{Teacher's Effort in Developing Learning Materials}

Based on data collection and results of analysis obtained from the finding it is found out that most teachers have not consciously set up the learning material in accordance with local needs, which involves the preservation of culture and tourism development. Learning materials related to both aspects are intended as an effort to improve the quality of human resources in the region, through the mastery of English language skills, which in the end are able to improve the welfare of the people of Tabanan regency. Most teachers are seldom to talk directly about culture and tourism in general in their class, but when they 
are asked to consider the development of tourism and cultural preservation in Tabanan, all teachers basically agree. They only need to consider the time frequency and presentation of the issue, since the focus of learning is not only about regional needs but also national and global market. Therefore, almost all teachers need to claim about 20 or 30 percent of all the material to put the certain issue in their teaching activities.

\section{Teachers' Agreement to Set Learning Materials and Evaluation by Regarding Cultural Preservation and Tourism Development in Tabanan District}

The observation and interview showed up some interesting findings. As what have been mentioned earlier, all subject teachers are trying their best to relate the English material with local/region needs. However only 5 of them are able to show syllabus or lesson plan that they have done regarding the activity. Some others are showing only printed textbook that they get from the government, while one teacher show students' worksheet that they buy from third party. Some of them even have difficulties to explain about the syllabus that they get. This might understandable since K13 is relatively new to be applied in their school, and they do not get proper training about K13.

Although both curriculum have mentioned that the learning process should also considering local needs, but the materials that is used is insufficient to accommodate the need. That's why the teachers think that the materials should be supplied by the local government and set up in certain way to accommodate our research study, the culture reservation and tourism development. But of course, those extra material need lots of funding so it might depends on the teachers or the local government decision.

\section{Conclusion}

There are several conclusions can be made from this research. First, 3 senior high schools as research sites in Tabanan are using K13, while the other two are still using KTSP. Teachers in K13 schools are mostly leaving the teaching sources from printed textbook that is given by the central government, while teachers in KTSP schools are primary using printed material that are supplied by the third party. However all teachers are trying their best to find other additional material that is fit their students need, as long as that is not against the syllabus or the applied curriculum.

Secondly, most teachers are not setting up material based on their regions' need, as well as relating the material with cultural preservation and tourism development. This can be seen from the primary printed material that they use, a textbook from central government, where that material is less accommodating local issue. But some teachers already make some progress, unconsciously, by asking the students to find other printed materials like hotel brochures or tourism magazine that has several explanations about tourism objects in Tabanan, or several narrative stories about legend that they know in their village or region. Later on the teachers will ask the students to present their work in form of oral presentation or dialogue in the classroom. This activity, 
more or less, will add some knowledge for students about tourism issue in their region's area, as well as adding some valuable character about cultural preservation as well as a bit of tourism development.

The last one is that all the teachers agree that they should include culture preservation and tourism development in their material as well as in their English learning activity in the class. However they must mind the time frequency and amount of material so that it won't conflict the syllabus and the applied curriculum. The teacher thinks it is necessary to put the idea of culture preservation and tourism development since they live in the island that is famous for its tourism destination as well as preparing young generation to make the tourism and culture sustain in the island.

\section{References}

Al Qur'an, Marwan N. (2010). How to Use Multiple Case Studies in International Business Research: Methodological Aspects. International Review of Business Research Papers Volume 6. Number 2. July 2010 Pp.104. Downloaded on October 30, 2015 from: http://www.bizresearchpapers.com/8.Marwan.pdf

Alberta. Tourism Development Guide. Canada. Downloaded on September 3, (2015) from: https://www.albertacanada.com/1Tourism_Development_Guide.pdf.

Bappenas. (2014). Perkembangan Pembangunan Provinsi Bali 2014. Seri Analisa Pembangunan Daerah. Downloaded on September 10, 2015 from: http://simreg.bappenas.go.id/document/Publikasi/DokPub/07.\%20Anprov $\% 20$ Bali.pdf

Disparda Bali. (2015). 10 Besar Kunjungan Obyek Wisata di Bali Th.2003-2014. Downloaded on September 9, 2015 from: www.baliprov.go.id/files/subdomain/disparda/RANKING.DTW\%202003 -2014.xls

Kitao, Kenji. Kitao S. Kathleen. (1997). Selecting and Developing Teaching/Learning Materials. Retrieved on September 2, 2015 from: http://iteslj.org/Articles/Kitao-Materials.html

Koentjaraningrat. (2002). Kebudayaan Mentalitas dan Pembangunan. Jakarta. Pt. Gramedia

Lewis, Beth. (2015). TLM - Teaching/Learning Materials. Retrieved on September 7, 2015 from: http://k6educators.about.com/od/educationglossary/g/gtlm.htm

Perry, Dewayne E. (2004). Case Studies. Power Point Presentation. Downloaded on October 10, 2015 from:

http://users.ece.utexas.edu/ perry/education/382c/L06.pdf

Tarigan, Agita. (2015). Indonesia peringkat ke-28 berbahasa Inggris. Retrieved on September 9, 2015 from: http://www.antaranews.com/berita/477154/indonesia-peringkat-ke-28berbahasa-inggris.

Thomas-Hoffman, Elizabeth A. Cultural Preservation and Protection. Downloaded on September 9, 2015 from: 
http://www.mesacc.edu/ bricl07041/un/hs/culture.pdf

UNESCO. (2015). Basic Leaning Materials. Initiative. Retrieved on October 9, 2015 from: http://www.unesco.org/education/blm/chap1_en.php

UNESCO. (2015). World Heritage. Retrieved on October 9, 2015 from: http://whc.unesco.org/en/about/

UNWTO. Sustainable Development of Tourism. Retrieved on September 9, 2015 from: http://sdt.unwto.org/content/about-us-5 